\title{
Nesterenkonia halophila sp. nov., a moderately halophilic, alkalitolerant actinobacterium isolated from a saline soil
}

Correspondence

Wen-Jun Li

wjli@ynu.edu.cn

\author{
Wen-Jun Li, ${ }^{1} \dagger$ Yu-Oin Zhang, ${ }^{1,2} \uparrow$ Peter Schumann, ${ }^{3}$ Hong-Yu Liu, ${ }^{2}$ \\ $\mathrm{Li}-\mathrm{Yan} \mathrm{Yu},{ }^{2}$ Yue-Oin Zhang, ${ }^{2} \dagger$ Erko Stackebrandt, ${ }^{3}$ Li-Hua $\mathrm{Xu}{ }^{1}$ \\ and Cheng-Lin Jiang ${ }^{1}$
}
${ }^{1}$ The Key Laboratory for Microbial Resources of the Ministry of Education, PR China, and Laboratory for Conservation and Utilization of Bio-Resources, Yunnan Institute of Microbiology, Yunnan University, Kunming, Yunnan 650091, PR China
${ }^{2}$ Institute of Medicinal Biotechnology, Chinese Academy of Medical Sciences \& Peking Union Medical College, Beijing 100050, PR China
${ }^{3} \mathrm{DSMZ}$ - Deutsche Sammlung von Mikroorganismen und Zellkulturen GmbH, Inhoffenstrasse 7B, D-38124 Braunschweig, Germany

\begin{abstract}
A Gram-positive, non-motile, moderately halophilic, alkalitolerant actinobacterium, designated strain YIM $70179^{\top}$, was isolated from a saline soil sample collected from Xinjiang Province, northwest China, and was subjected to a polyphasic taxonomic study. The cell-wall peptidoglycan type of strain YIM $70179^{\top}$ was A4 $\alpha$, L-Lys-Gly-L-Glu. Cells of the isolate contained diphosphatidylglycerol, phosphatidylglycerol, phosphatidylinositol and an unknown glycolipid, MK-8 as major menaquinone and anteiso- $C_{15: 0}$, anteiso- $C_{17: 0}$ and iso- $C_{16: 0}$ as major fatty acids. The DNA G $+\mathrm{C}$ content was $68.4 \mathrm{~mol} \%$. Phylogenetic analysis based on 16S rRNA gene sequences showed that strain YIM $70179^{\top}$ fell within the radiation of species of the genus Nesterenkonia. Levels of 16S rRNA gene sequence similarity between strain YIM $70179^{\top}$ and the type strains of recognized Nesterenkonia species were below $97 \%$, except to Nesterenkonia halobia DSM $20541^{\top}(99.6 \%)$, but these two strains exhibited a low level of DNA-DNA relatedness (18.4\%). Based on genetic and phenotypic evidence, it is proposed that strain YIM $70179^{\top}$ represents a novel species of the genus Nesterenkonia, for which the name Nesterenkonia halophila sp. nov. is proposed. The type strain is YIM $70179^{\top}$ (=DSM $16378^{\top}$ $=$ KCTC $19048^{\top}$ ).
\end{abstract}

The genus Nesterenkonia was first proposed by Stackebrandt et al. (1995) with the reclassification of Micrococcus halobius (Onish \& Kamekura, 1972) as Nesterenkonia halobia. The description of the genus was later emended by Collins et al. (2002) and Li et al. (2005). At the time of writing, the genus comprises seven recognized species, namely $N$. halobia (Stackebrandt et al., 1995), N. lacusekhoensis (Collins et al., 2002), N. halotolerans and N. xinjiangensis ( $\mathrm{Li}$ et al., 2004), N. sandarakina and N. lutea (Li et al., 2005) and N. aethiopica (Delgado et al., 2006). Here we present the description of strain YIM $70179^{\mathrm{T}}$, which is shown to represent a novel species of the genus Nesterenkonia.

†These authors contributed equally to this work.

The GenBank/EMBL/DDBJ accession number for the 16S rRNA gene sequence of strain YIM $70179^{\top}$ is AY820953.
Strain YIM $70179^{\mathrm{T}}$ was isolated from a saline soil sample collected from Xinjiang Province, north-west China, by using the dilution plating method. For isolation, MSG medium supplemented with $25 \% \mathrm{KCl}(\mathrm{w} / \mathrm{v})$ was used. The MSG medium was modified from S-G medium (Sehgal \& Gibbons, 1960) and contained (per litre distilled water): $7.5 \mathrm{~g}$ Casamino acids, $10.0 \mathrm{~g}$ yeast extract, $3.0 \mathrm{~g}$ trisodium citrate, $2.0 \mathrm{~g} \mathrm{NaCl}, 2.0 \mathrm{~g} \mathrm{MgCl}_{2} .6 \mathrm{H}_{2} \mathrm{O}, 1.0 \mathrm{~g} \mathrm{MgSO}_{4} .7 \mathrm{H}_{2} \mathrm{O}$,

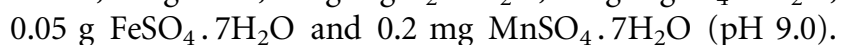
Sterilized saturated $\mathrm{NaOH}$ was used to adjust the $\mathrm{pH}$. Plates were incubated at $28{ }^{\circ} \mathrm{C}$ for 2 weeks. Strain YIM $70179^{\mathrm{T}}$ was maintained on MSG agar slants that contained $10 \% \mathrm{KCl}(\mathrm{w} /$ v) at $4{ }^{\circ} \mathrm{C}$ and as glycerol suspensions $\left(20 \%\right.$, v/v) at $-20{ }^{\circ} \mathrm{C}$. Biomass for chemical and molecular systematic studies was obtained from MSG agar supplemented with $10 \% \mathrm{KCl}(\mathrm{w} / \mathrm{v})$ incubated at $28{ }^{\circ} \mathrm{C}$ for about $4-5$ days.

Gram staining and the $\mathrm{KOH}$ lysis test were carried out according to Gram (1884) and Cerny (1978), respectively. 
Morphology and motility of cells (tested at various growth stages) on MSG agar containing $10 \% \mathrm{KCl}$ were examined by light microscopy (model $\mathrm{BH} 2$; Olympus) and transmission electron microscopy (H-800; Hitachi). For transmission electron microscopy observation, cells were negatively stained with $1 \%(\mathrm{w} / \mathrm{v})$ phosphotungstic acid after air drying. Colony morphology and colour were observed on MSG and PYGV agar media (Staley, 1968) containing $10 \% \mathrm{KCl}$ after incubation at $28{ }^{\circ} \mathrm{C}$ for 2 days. Colour was determined by comparing the cultures with the most suitable colour chips from Kelly (1964). Growth was tested at $0,4,10,28,37,40,45$ and $55{ }^{\circ} \mathrm{C}$ on trypticase soy agar (TSA) containing $10 \% \mathrm{KCl}$. Experiments investigating tolerance to $\mathrm{NaCl}, \mathrm{KCl}$ and $\mathrm{MgCl}_{2} \cdot 6 \mathrm{H}_{2} \mathrm{O}$ were carried out by using non-salt-containing trypticase soy broth (TSB) as the basal medium. The following $\mathrm{NaCl}, \mathrm{KCl}$ and $\mathrm{MgCl}_{2} \cdot 6 \mathrm{H}_{2} \mathrm{O}$ concentrations $(\mathrm{w} / \mathrm{v})$ were tested: $0,0.5,1,3,5,10,15,20,25$ and $30 \%$. For $\mathrm{pH}$ endurance experiments, the following buffer solutions were used: $\mathrm{pH}$ 5.0-5.5, $0.1 \mathrm{M}$ citric acid/ $0.1 \mathrm{M}$ sodium citrate; $\mathrm{pH}$ 6.0-8.0, $10 \mathrm{mM}$ HEPES/0.5 M $\mathrm{NaOH}$; pH 8.5-11.5, $0.5 \mathrm{M} \mathrm{NaHCO}_{3} / 0.5 \mathrm{M} \mathrm{Na}_{2} \mathrm{CO}_{3}$. Liquid TSB (containing $10 \% \mathrm{KCl}$ ) cultures were cultivated in tubes at $28{ }^{\circ} \mathrm{C}$ for 14 days. Tests investigating the ability of the novel strain to use sole carbon sources and peptonization activity and coagulation of milk were performed according to the methods described by Shirling \& Gottlieb (1966). Tests for hydrolysis of casein, starch and Tweens 20 and $80, \mathrm{H}_{2} \mathrm{~S}$ production and the methyl red and Voges-Proskauer reactions were performed as described by Smibert \& Krieg (1981), by using the basal medium supplemented with $10 \%$ (w/v) KCl. Activity of several enzymes, such as lipase, lysine decarboxylase and arginine dihydrolase, was determined by using API ID32 E test kits. Nitrate reduction, gelatin liquefaction and acid production were tested by using the API Coryne system according to the manufacturer's instructions (bioMérieux), except that the cell suspension to inoculate the systems was prepared by using sterilized artificial seawater supplemented with $10 \%(\mathrm{w} / \mathrm{v}) \mathrm{KCl}$. The oxidase reaction was tested by using API oxidase reagent. Catalase activity was determined based on production of bubbles after the addition of a drop of $3 \% \mathrm{H}_{2} \mathrm{O}_{2}$.

Purified peptidoglycan preparations were obtained according to the method described by Schleifer \& Kandler (1972). Amino acids and peptides in cell-wall hydrolysates were analysed by two-dimensional ascending TLC on cellulose plates (Merck) by using the solvent systems of Schleifer \& Kandler (1972). The amino-terminal amino acid of the interpeptide bridge was determined by dinitrophenylation as described by Schleifer (1985). Molar ratios of amino acids were determined by GC and GC-MS of $\mathrm{N}$ heptafluorobutyryl amino acid isobutyl esters (MacKenzie, 1987). Analysis of enantiomers of peptidoglycan amino acids was performed by GC of $\mathrm{N}$-pentafluoropropionyl amino acid isopropyl esters (Frank et al., 1980) on an L-chirasil Val column (Macherey-Nagel) as described by Groth et al. (1997). Analyses of polar lipids and menaquinones followed published procedures (Groth et al.,
1999). Analysis of the whole-cell fatty acid pattern followed the methods of Miller (1982) by using the MIDI system (Microbial ID, Inc.).

Extraction of genomic DNA was performed as described by $\mathrm{Xu}$ et al. (2003). Primers PA (forward; positions 8-27 according to the Escherichia coli numbering system; 5'AGAGTTTGATCCTGGCTCAG-3') and PB (reverse; 1523-1504; 5'-AAGGAGGTGATCCAGCCGCA-3') were used for amplification of the 16S rRNA gene sequence of the novel isolate, and the PCR products were purified and sequenced as described by Cui et al. (2001).

Phylogenetic analysis was performed by using the software package MEGA version 2.1 (Kumar et al., 2001) after multiple alignments of the data with CLUSTAL_X (Thompson et al., 1997). Distances were calculated according to Kimura's twoparameter correction (Kimura, 1980, 1983) and cluster analysis was performed with the neighbour-joining (Saitou \& Nei, 1987) and maximum-likelihood (Felsenstein, 1981) methods. Bootstrap analysis was used to evaluate the tree topology of the neighbour-joining data by performing 1000 resamplings (Felsenstein, 1985).

The DNA base composition of strain YIM $70179^{\mathrm{T}}$ was determined by reversed-phase HPLC of nucleosides according to Mesbah et al. (1989). DNA-DNA hybridization was carried out applying the optical renaturation method (De Ley et al., 1970; Huß et al., 1983; Jahnke, 1992) under optimal hybridization conditions.

When grown on SMG agar for $48 \mathrm{~h}$, cells of strain YIM $70179^{\mathrm{T}}$ were aerobic, Gram-positive, non-motile, nonspore-forming cocci, about $1.2-1.8 \mu \mathrm{m}$ in diameter. Colonies were ivory white, circular, lubricious and opaque. Growth occurred from 4 to $45{ }^{\circ} \mathrm{C}$ on TSA containing $10 \%$ KCl. Strain YIM $70179^{\mathrm{T}}$ was able to grow in TSB supplemented with $10 \% \mathrm{KCl}(\mathrm{w} / \mathrm{v})$ or $\mathrm{NaCl}$, when the initial $\mathrm{pH}$ ranged from 6.0 to 10.5 . In TSB broth lacking salts, growth was observed with $0.5-30 \% \mathrm{KCl}$ or $\mathrm{NaCl}$ or $\mathrm{MgCl}_{2} \cdot 6 \mathrm{H}_{2} \mathrm{O}$ (w/v) added. Good growth occurred at $28^{\circ} \mathrm{C}$, at an initial $\mathrm{pH}$ of $7.0-8.0$ and in the presence of $10.0 \% \mathrm{KCl}$ or $\mathrm{NaCl}$. Detailed physiological properties of strain YIM $70179^{\mathrm{T}}$ are listed in Table 1 and in the species description below.

Chemotaxonomically, the peptidoglycan type of strain YIM $70179^{\mathrm{T}}$ was A4 $\alpha$ (Schleifer \& Kandler, 1972), L-Lys-Gly-LGlu, in which L-lysine is in position 3 of the peptide subunit and glycine and L-glutamic acid form the interpeptide bridge. The isoprenoid quinones were menaquinones of type MK-8, MK-9 and MK-7 (ratio 81:7:6). Polar lipids consisted of phosphatidylinositol, phosphatidylglycerol, diphosphatidylglycerol and an unidentified glycolipid. Major cellular fatty acids were anteiso- $\mathrm{C}_{15: 0}$ $(47.1 \%)$, anteiso- $\mathrm{C}_{17: 0}(31.1 \%)$ and iso- $\mathrm{C}_{16: 0}(11.2 \%)$; the detailed fatty acid profile of strain YIM $70179^{\mathrm{T}}$ is given in the species description below.

Analysis of the almost-complete 16S rRNA gene sequence $(1484 \mathrm{nt})$ of strain YIM $70179^{\mathrm{T}}$ with those of a broad range 
Table 1. Comparison of phenotypic properties of strain $\mathrm{YIM} 70179^{\top}$ and its closest phylogenetic neighbour, $N$. halobia DSM $20541^{\top}$

Data for strain YIM $70179^{\mathrm{T}}$ were obtained in the present study with TSB as the basal medium. Data for N. halobia DSM $20541^{\mathrm{T}}$ were taken from Stackebrandt et al. (1995) and Mota et al. (1997) except where indicated. The two strains share the following characteristics. Cells are Grampositive, non-motile, non-spore-forming cocci. Positive for catalase, ornithine decarboxylase, arginine dihydrolase, lysine decarboxylase, $\alpha$ glucosidase, $\beta$-glucosidase, $\beta$-galactosidase, $\alpha$-maltosidase and aesculin hydrolysis, but negative for $\alpha$-galactosidase, $N$-acetylglucosaminidase, $\beta$ glucuronidase, L-aspartic arylamidase, urease, gelatin liquefaction, methyl red and Voges-Proskauer tests and $\mathrm{H}_{2} \mathrm{~S}$ and indole production. The two strains have the same peptidoglycan type and polar lipid composition.

\begin{tabular}{|c|c|c|}
\hline Characteristic & YIM $70179^{\mathrm{T}}$ & N. halobia DSM $20541^{\mathrm{T}}$ \\
\hline Cell arrangement & Single, in pairs or in clusters & Pairs, tetrads or irregular clusters \\
\hline Colony pigmentation (PYGV medium) & Ivory white & Colourless \\
\hline pH tolerance & $6.0-10.5$ & $5.5-10.0^{*}$ \\
\hline Lipase & + & - \\
\hline Oxidase activity & - & + \\
\hline Nitrate reduction & + & - \\
\hline Major menaquinone(s) & MK-8 & MK-8, MK-9 \\
\hline Major fatty acids $(>10 \%)$ & anteiso- $\mathrm{C}_{15: 0}$, anteiso- $\mathrm{C}_{17: 0}$, iso- $\mathrm{C}_{16: 0}$ & anteiso- $\mathrm{C}_{15: 0}$, iso- $\mathrm{C}_{17: 0}$ \\
\hline DNA G $+C$ content $(\mathrm{mol} \%)$ & 68.4 & 71.5 \\
\hline
\end{tabular}

${ }^{\star}$ Determined in the present study with TSB as basal medium.

of homologous actinobacterial taxa revealed that the closest relative of strain YIM $70179^{\mathrm{T}}$ was $N$. halobia DSM $20541^{\mathrm{T}}$ (sequence similarity of $99.6 \%$ ); levels of $16 \mathrm{~S}$ rRNA gene sequence similarity between strain YIM $70179^{\mathrm{T}}$ and the other actinobacterial test strains were less than $97 \%$. Fig. 1 shows the phylogenetic position of strain YIM $70179^{\mathrm{T}}$ within the radiation of type strains of all recognized Nesterenkonia species.

The level of DNA-DNA relatedness of $18.4 \%$ (mean value of two experiments) between strain YIM $70179^{\mathrm{T}}$ and its closest phylogenetic neighbour, N. halobia DSM $20541^{\mathrm{T}}$, was significantly below the value of $70 \%$ which is considered to be the threshold for the delineation of genomic species (Wayne et al., 1987). Additionally, strain YIM $70179^{\mathrm{T}}$ could be differentiated from N. halobia DSM $20541^{\mathrm{T}}$ on the basis of several phenotypic characteristics (Table 1).

On the basis of its phenotypic and genotypic properties, strain YIM $70179^{\mathrm{T}}$ is considered to represent a novel species of the genus Nesterenkonia, for which the name Nesterenkonia halophila sp. nov. is proposed.

\section{Description of Nesterenkonia halophila sp. nov.}

Nesterenkonia halophila (ha.lo' phi.la. Gr. n. hals, halos salt; Gr. adj. philos loving; N.L. fem. adj. halophila salt-loving, referring to the ability to grow at high salt concentrations).

Cells are Gram-positive, non-motile, non-spore-forming cocci. Colony colour is ivory white. Colonies are circular, opaque and approximately $0.5-1.0 \mathrm{~mm}$ in diameter after $48 \mathrm{~h}$ at $28{ }^{\circ} \mathrm{C}$. Growth occurs at $0.5-30 \%(\mathrm{w} / \mathrm{v}) \mathrm{NaCl}, \mathrm{KCl}$ or $\mathrm{MgCl}_{2} \cdot 6 \mathrm{H}_{2} \mathrm{O}$ (optimum growth at $10 \%$, w/v). Good growth occurs at initial $\mathrm{pH}$ of $7.0-8.0$ and at $28{ }^{\circ} \mathrm{C}$. Positive for peptonization and coagulation of milk, but negative for production of $\mathrm{H}_{2} \mathrm{~S}$, ammonia and melanin. Other phenotypic characteristics are given in Table 1. Utilizes L-arabinose, xylose, D-fructose, cellulose, D-mannose, glucose, malonate, mannitol, salicin and acetamide, but not arabitol, adonitol, cellobiose, inositol or rhamnose as the only carbon source. Negative for hydrolysis of casein and Tweens 20 and 80 . No acid production from glucose, ribose, xylose, mannitol, malonate, lactose, sucrose or glycogen. The peptidoglycan type is A $4 \alpha$, L-Lys-Gly-L-Glu.

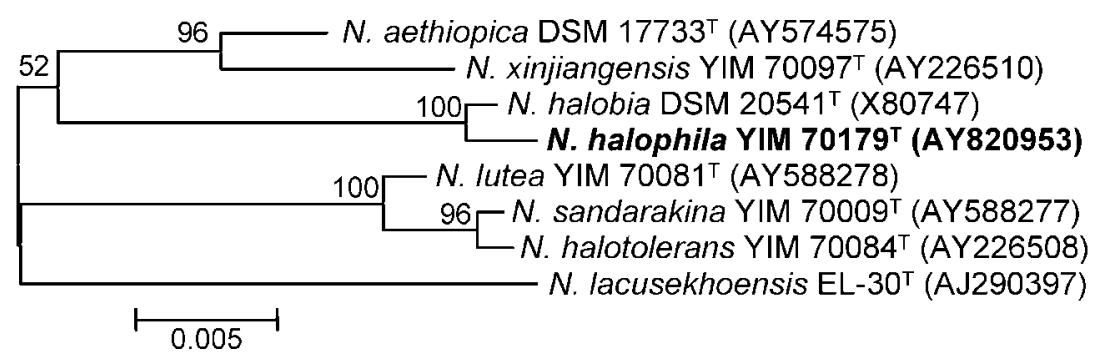

Fig. 1. Phylogenetic dendrogram obtained by distance matrix analysis of $16 \mathrm{~S}$ rRNA gene sequences, showing the position of strain YIM $70179^{\top}$ among its phylogenetic neighbours. Numbers on branch nodes are bootstrap values (1000 resamplings; only values $>50 \%$ are given). Bar, $0.5 \%$ sequence divergence. 
The polar lipids contain phosphatidylinositol, phosphatidylglycerol, diphosphatidylglycerol and an unidentified glycolipid. The isoprenoid quinones are menaquinones of type MK-8, MK-9 and MK-7 (ratio 81:7:6). The cellular fatty acid profile comprises anteiso- $\mathrm{C}_{15: 0}(47.1 \%)$, anteiso$\mathrm{C}_{17: 0}(31.1 \%)$, iso- $\mathrm{C}_{16: 0}(11.2 \%), \mathrm{C}_{16: 0}(3.3 \%)$, iso- $\mathrm{C}_{15: 0}$ $(2.4 \%)$, iso- $\mathrm{C}_{17: 0}(1.3 \%)$, iso- $\mathrm{C}_{16: 1}(0.9 \%)$, anteiso$\mathrm{C}_{17: 1} \omega 9 \mathrm{c} \quad(0.5 \%), \quad$ iso- $\mathrm{C}_{14: 0} \quad(0.4 \%)$, anteiso- $\mathrm{C}_{15: 1}$ $(0.4 \%), \mathrm{C}_{16: 1} \omega 7 c(0.3 \%)$ and iso- $\mathrm{C}_{15: 1}(0.2 \%)$. The DNA G $+\mathrm{C}$ content of the type strain is $68.4 \mathrm{~mol} \%$.

The type strain, YIM $70179^{\mathrm{T}}\left(=\mathrm{DSM} 16378^{\mathrm{T}}=\mathrm{KCTC}\right.$ $19048^{\mathrm{T}}$ ), was isolated from a saline soil sample in Xinjiang Province, north-west China.

\section{Note added on revision}

Since this article was submitted for publication, an additional species of the genus has been described, Nesterenkonia jeotgali (Yoon et al., 2006).

\section{Acknowledgements}

This research was supported by the National Facilities and Information Infrastructure for Science and Technology (grant no. 2006DKA21203), National Basic Research Program of China (project no. 2004CB719601), National Natural Science Foundation of China (project no. 30600001) and a Key Project of the Chinese Ministry of Education (no. 206139). W.-J. L. was also supported by the Program for New Century Excellent Talent in University (NCET).

\section{References}

Cerny, G. (1978). Studies on aminopeptidase for the distinction of Gram-negative from Gram-positive bacteria. Appl Microbiol Biotechnol 5, 113-122.

Collins, M. D., Lawson, P. A., Labrenz, M., Tindall, B. J., Weiss, N. \& Hirsch, P. (2002). Nesterenkonia lacusekhoensis sp. nov., isolated from hypersaline Ekho Lake, East Antarctica, and emended description of the genus Nesterenkonia. Int J Syst Evol Microbiol 52, 1145-1150.

Cui, X. L., Mao, P. H., Zeng, M., Li, W. J., Zhang, L. P., Xu, L. H. \& Jiang, C. L. (2001). Streptomonospora salina gen. nov., sp. nov., a new member of the family Nocardiopsaceae. Int J Syst Evol Microbiol 51, 357-363.

De Ley, J., Cattoir, H. \& Reynaerts, A. (1970). The quantitative measurement of DNA hybridization from renaturation rates. Eur J Biochem 12, 133-142.

Delgado, O., Quillaguaman, J., Bakhtiar, S., Mattiasson, B., Gessesse, A. \& Hatti-Kaul, R. (2006). Nesterenkonia aethiopica sp. nov., an alkaliphilic, moderate halophile isolated from an Ethiopian soda lake. Int J Syst Evol Microbiol 56, 1229-1232.

Felsenstein, J. (1981). Evolutionary trees from DNA sequences: a maximum likelihood approach. J Mol Evol 17, 368-376.

Felsenstein, J. (1985). Confidence limits on phylogenies: an approach using the bootstrap. Evolution 39, 783-791.

Frank, H., Rettenmeier, A., Weicker, H., Nicholson, G. J. \& Bayer, E. (1980). A new gas chromatographic method for determination of amino acid levels in human serum. Clin Chim Acta 105, 201-211.

Gram, H. C. (1884). Über die isolierte Färbung der Schizomyceten in Schnitt- und Trockenpräparaten. Fortschr Med 2, 185-189 (in German).
Groth, I., Schumann, P., Rainey, F. A., Martin, K., Schuetze, B. \& Augsten, K. (1997). Demetria terragena gen. nov., sp. nov., a new genus of actinomycetes isolated from compost soil. Int J Syst Bacteriol 47, 1129-1133.

Groth, I., Schumann, P., Martin, K., Schuetze, B., Augsten, K., Kramer, I. \& Stackebrandt, E. (1999). Ornithinicoccus hortensis gen. nov., sp. nov., a soil actinomycete which contains L-ornithine. Int J Syst Bacteriol 49, 1717-1724.

Huß, V. A. R., Festl, H. \& Schleifer, K. H. (1983). Studies on the spectrophotometric determination of DNA hybridization from renaturation rates. Syst Appl Microbiol 4, 184-192.

Jahnke, K. D. (1992). BASIC computer program for evaluation of spectroscopic DNA renaturation data from GILFORD SYSTEM 2600 spectrophotometer on a PC/XT/AT type personal computer. J Microbiol Methods 15, 61-73.

Kelly, K. L. (1964). Inter-Society Color Council - National Bureau of Standards Color-Name Charts Illustrated with Centroid Colors. Washington, DC: US Government Printing Office.

Kimura, M. (1980). A simple method for estimating evolutionary rates of base substitutions through comparative studies of nucleotide sequences. J Mol Evol 16, 111-120.

Kimura, M. (1983). The Neutral Theory of Molecular Evolution. Cambridge: Cambridge University Press.

Kumar, S., Tamura, K., Jakobsen, I.-B. \& Nei, M. (2001). MEGA2: molecular evolutionary genetics analysis software. Bioinformatics 17, 1244-1245.

Li, W. J., Chen, H. H., Zhang, Y. Q., Schumann, P., Stackebrandt, E., Xu, L. H. \& Jiang, C. L. (2004). Nesterenkonia halotolerans sp. nov. and Nesterenkonia xinjiangensis sp. nov., actinobacteria from saline soils in the west of China. Int J Syst Evol Microbiol 54, 837-841.

Li, W. J., Chen, H. H., Zhang, Y. Q., Schumann, P., Stackebrandt, E., Xu, L. H. \& Jiang, C. L. (2005). Nesterenkonia sandarakina sp. nov. and Nesterenkonia lutea sp. nov., novel actinobacteria, and emended description of the genus Nesterenkonia. Int J Syst Evol Microbiol 55, 463-466.

MacKenzie, S. L. (1987). Gas chromatographic analysis of amino acids as the N-heptafluorobutyryl isobutyl esters. J Assoc Off Anal Chem 70, 151-160.

Mesbah, M., Premachandran, U. \& Whitman, W. B. (1989). Precise measurement of the $\mathrm{G}+\mathrm{C}$ content of deoxyribonucleic acid by highperformance liquid chromatography. Int J Syst Bacteriol 39, 159-167.

Miller, L. T. (1982). Single derivatization method for routine analysis of bacterial whole-cell, fatty acids methyl esters, including hydroxy acids. J Clin Microbiol 16, 584-586.

Mota, R. R., Marquez, C., Arahal, D., Mellado, E. \& Ventosa, A. (1997). Polyphasic taxonomy of Nesterenkonia halobia. Int J Syst Bacteriol 47, 1231-1235.

Onish, H. \& Kamekura, M. (1972). Micrococcus halobius sp. nov. Int J Syst Bacteriol 22, 233-236.

Saitou, N. \& Nei, M. (1987). The neighbor-joining method: a new method for reconstructing phylogenetic trees. Mol Biol Evol 4, 406425.

Schleifer, K. H. (1985). Analysis of the chemical composition and primary structure of murein. Methods Microbiol 18, 123-156.

Schleifer, K. H. \& Kandler, O. (1972). Peptidoglycan types of bacterial cell walls and their taxonomic implications. Bacteriol Rev 36, 407-477.

Sehgal, S. N. \& Gibbons, N. E. (1960). Effect of metal ions on the growth of Halobacterium cutirubrum. Can J Microbiol 6, 165-169.

Shirling, E. B. \& Gottlieb, D. (1966). Methods for characterization of Streptomyces species. Int J Syst Bacteriol 16, 313-340. 
Smibert, R. M. \& Krieg, N. R. (1981). General characterization. In Manual of Methods for General Bacteriology, pp. 409-443. Edited by P. Gerhardt, R. G. E. Murray, R. N. Costilow, E. W. Nester, W. A. Wood, N. R. Krieg \& G. B. Phillips. Washington, DC: American Society for Microbiology.

Stackebrandt, E., Koch, C., Gvozdiak, O. \& Schumann, P. (1995). Taxonomic dissection of the genus Micrococcus: Kocuria gen. nov., Nesterenkonia gen. nov., Kytococcus gen. nov., Dermacoccus gen. nov., and Micrococcus Cohn 1872 gen. emend. Int J Syst Bacteriol 45, 682-692.

Staley, J. T. (1968). Prosthecomicrobium and Ancalomicrobium, new prosthecate freshwater bacteria. J Bacteriol 95, 1921-1944.

Thompson, J. D., Gibson, T. J., Plewniak, F., Jeanmougin, F. \& Higgins, D. G. (1997). The CLUSTAL_X windows interface: flexible strategies for multiple sequence alignment aided by quality analysis tools. Nucleic Acids Res 25, 4876-4882.

Wayne, L. G., Brenner, D. J., Colwell, R. R., Grimont, P. A. D., Kandler, O., Krichevsky, M. I., Moore, L. H., Moore, W. E. C., Murray, R. G. E. \& other authors (1987). International Committee on Systematic Bacteriology. Report of the ad hoc committee on reconciliation of approaches to bacterial systematics. Int J Syst Bacteriol 37, 463-464.

Xu, P., Li, W. J., Xu, L. H. \& Jiang, C. L. (2003). A microwave-based method for genomic DNA extraction from actinomycetes. Microbiology (Beijing) 30, 82-84 (in Chinese).

Yoon, J. H., Jung, S. Y., Kim, W., Nam, S. W. \& Oh, T. K. (2006).

Nesterenkonia jeotgali sp. nov., isolated from jeotgal, a traditional Korean fermented seafood. Int J Syst Evol Microbiol 56, 2587-2592. 